UDC 666.792:621.9.025.7

O.Yu. Fedorenko ${ }^{a}$, K.B. Bohdanova ${ }^{a}$, D.O. Fedorenko ${ }^{a}$, N.F. Lesnych ${ }^{b}$, N.M. Reheda ${ }^{a}$

\title{
LOW-MELTING GLASS-CERAMIC BONDS BASED ON OXIDE COMPOSITIONS FOR DIAMOND-ABRASIVE TOOLS
}

\author{
a National Technical University «Kharkiv Polytechnic Institute», Kharkiv, Ukraine \\ ${ }^{b}$ University of Applied Sciences, Technology, Business and Design, Wismar, Germany
}

\begin{abstract}
Rational characteristics of the structural-phase constituents of the diamond-bearing layer and required physical-mechanical and thermophysical properties of the bond were determined based on the results of computer simulation of the processes accompanying the manufacture of the diamond-abrasive tool. To assess the state of diamond, taking into account its brand and graininess, a structural criterion, $\Delta \mathrm{V}_{\mathrm{cr}}$, is proposed that characterizes the grain relative volume in which the stresses reach a critical level $\left(\Delta \mathrm{V}_{\mathrm{cr}}>10 \%\right)$ and cause the grains destruction. The composition is designed and the sintering conditions of the diamond-bearing layer are determined to ensure rational self-sharpening of grains during grinding. On the basis of the oxide compositions of the $\mathrm{R}_{2} \mathrm{O}-\left(\mathrm{Na}_{2} \mathrm{O}, \mathrm{K}_{2} \mathrm{O}\right)-\mathrm{B}_{2} \mathrm{O}_{3}-\mathrm{TiO}_{2}-\mathrm{SiO}_{2}$ system, a low-melting glass-ceramic bond is developed which have the following properties: thermal expansion coefficient of $6.9 \cdot 10^{-6} 1 /{ }^{\circ} \mathrm{C}$ and elastic modulus of $115 \mathrm{GPa}$. The lowmelting glass-ceramic bond provides the sintering of a diamond-bearing layer at the temperature of $620^{\circ} \mathrm{C}$. The dependence of the specific diamond's loss and the grains wear areas size on the grinding regimes was determined for fabricated diamond wheels. It was established that during the processing of hard alloys (VK-8) the self-sharpening of a tool occurs at the following process parameters: grinding speed of $30 \mathrm{~m} / \mathrm{s}$, cross-feed of $0.02 \mathrm{~mm} /$ double stroke. The analysis of the results of the topological parameters and electron microscopic studies of the diamond wheels after grinding allows us to develop a mechanism of the grains cutting capacity restoration, according to which the grinding with the diamond-abrasive tool occurs in self-sharpening mode that ensures an increase in its operation resource.
\end{abstract}

Keywords: diamond wheel, cutting ability, self-sharpening, diamond-bearing layer, vitrified bond, structural-phase components.

DOI: $10.32434 / 0321-4095-2019-124-3-158-165$

\section{Introduction}

Increased requirements for the quality of surface treatment of different products necessitate the improvement and creation of new high-performance tools for the machine-building, military-industrial, agricultural and mining industries. Diamond grinding is a high-performance method to process parts from metals, solid alloys and superhard non-metallic materials. Despite numerous studies in field of its improvement, the issue of increasing the productivity and resource efficiency of the diamond-abrasive tool (DAT) remain open [1-3]. One of the leading directions of increasing the efficiency of diamond abrasive processing is the use of diamond wheels on ceramic bonds, which, in comparison with metal or polymer bonds, reinforce the solidity of the diamondbearing layer, increase the permissible temperature of abrasive treatment and provide a high precision of parts processing. Diamond wheels on ceramic bonds allow treating the surfaces of metals and alloys, ceramic, glassceramics, glass and composite materials, including hybrids materials [3-5].

It is known that the cutting ability of DAT decreases due to the formation of wear zones on grains. In addition, the grinding efficiency is reduced dramatically as a result of clogging the working area with particles of processed material. An increase in the share of the diamond tool on ceramic bonds has been observed, which is related to their advantages (high processing capacity, heat resistance, ability to

(C) O.Yu. Fedorenko, K.B. Bohdanova, D.O. Fedorenko N.F. Lesnych N.M. Reheda, 2019

O.Yu. Fedorenko, K.B. Bohdanova, D.O. Fedorenko, N.F. Lesnych, N.M. Reheda 
self-sharpening and prolonged service life). The analysis of information concerning the sphere of manufacturing diamond wheels shows that the number of works devoted to the diamond wheels has increased by more than 2.5 times over the last decade. However, the number of publications relating to the circles on the ceramic bond is only $8 \%$.

The main fault of the existing ceramic bonds for DAT is connected with the high sintering temperature of such ceramic matrix composites (more than $800^{\circ} \mathrm{C}$ ). Therefore, typical ceramic bonds are used primarily for manufacturing a grinding tool with temperature-resistant abrasives (cubonite or corundum) $[5,6]$. Sintering of diamond-containing composites under such conditions causes the premature failure of grains due to stresses occurring in them; in addition, graphitization makes it impossible to use typical ceramic bonds in the manufacture of DAT $[7,8]$.

It is known, however, that the ceramic bond determines the ability to rationally self-sharpening of DAT due to the regeneration of the working surface of diamond wheels during the grinding by updating the cutting surfaces of diamonds, uncovering new ones, and removing of blunted grains that increases the productivity of processing and the economic efficiency of using the tool $[2,6]$. Therefore, the use of ceramic diamond wheels will increase the processing capacity and expand the scope of the tool.

In view of the above, the aim of the work is to fabricate high resource diamond-abrasive tools with the use of low-melting glass-ceramic bonds with specified properties. This will ensure the preservation of the integrity of the grains when sintering the diamond-containing layer at the stage of the manufacture of tools, improve the diamond retention and create the conditions for grinding in a mode of rational self-sharpening.

\section{Experimental}

The study was conducted in several stages that included:

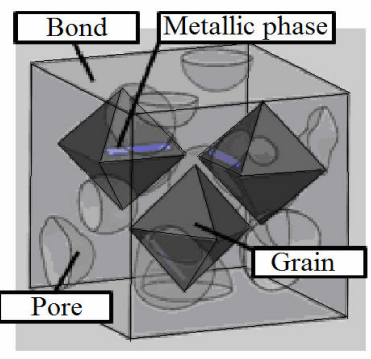

a

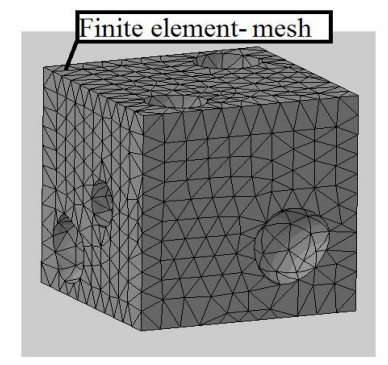

b
- theoretical analysis of the process of sintering of the diamond-bearing layer of the tool using the micro-level 3D modeling;

- the optimization of qualitative and quantitative characteristics of components of diamond-bearing layer with the use of mathematical planning of simulation experiments;

- the development of a low-melting vitrified bond with the specified properties and determination of the composition of a diamond-containing ceramicmatrix composite with a reduced temperature of sintering;

- the manufacture of the tool samples for which the study of structure and properties were conducted.

3D simulation of the sintering of diamondbearing layer and diamond grinding processes was carried out using software packages COSMOSWorks, ANSYS, ABAQUS, calculations in which are based on the finite element method (MKE). The simulation method included the following steps: the 3D models development of a system that displays the features of the elemental volume of a diamond wheel; the grid construction and its condensation in the places of metal inclusions in the grains, as well as on the contact surfaces of system elements; the task of load parameters (pressure of pressing and temperature of sintering corresponding to the conditions of the manufacture of diamond wheels); and determination of physical and mechanical and thermophysical properties for all model elements [9]. The fragment of the bond (Fig. 1) is performed in the form of a rectangular parallelepiped, in which there are pores of complex form. Diamond grains were performed with the geometry of the octahedron; the grain size was chosen depending on the grain size of the considered diamond powders. The grains contain the inclusions of a metal catalyst (further metallophase) in the form of arbitrarily oriented plates, volumetric content of which depends on the grade of diamonds (from 0.6 to $7.5 \%$ for grades $\mathrm{AC} 15$ and $\mathrm{AC} 2$, respectively). As a criterion of destruction, the

Fig. 1. 3D model of the system «metal phase-grain-bond-pore» (a), construction of the finite element network (b), loading scheme (c) and a stress-strain state diagram (SSS) (d) in the study of diamond-bearing layer sintering processes 
maximum equivalent stresses was considered that was calculated according to the Mohr-Coulomb theory taking into account the amendments of Pysarenko-Lebediev for brittle bodies [10] and the relative volume of elements of the system (grains or bonds).

The development of vitrified bond with specified properties involved the choice of model compositions in the oxide system $\mathrm{R}_{2} \mathrm{O}\left(\mathrm{Na}_{2} \mathrm{O}, \mathrm{K}_{2} \mathrm{O}\right)-\mathrm{B}_{2} \mathrm{O}_{3}-\mathrm{TiO}_{2}-\mathrm{SiO}_{2}$; the predictive calculation of their technological, thermophysical and physical-mechanical properties using known methods [11,12]; the development of the composition of low-melting glass component based on the solution of the optimization problem taking into account the constraints adopted by the results of simulation; the determination of composition of composite; and the research of topological characteristics of the surface after grinding (using laser scanning microscope KEYENCE VK-9700K) and features of microstructure (using laser electron microscope JSM-6390 LV).

The average size of abrasion zones of the grain $\left(\mathrm{S}_{\mathrm{gr}}\right)$ was measured by means of a laser scanning microscope. The specific loss of diamonds when grinding was determined according to the standard method which is based on the determination of the degree of wear of the diamond-bearing layer by the loss of the tool weight after the tests.

Soda ash, potash, boric acid, lithium carbonate, titanium dioxide and quartz sand from the Novoselivske deposit (Kharkiv region, Ukraine) were used to make the low-melting component of the vitrified bond. To increase the bond wear resistance, $\mathrm{SiC}$ was added in the amount of $20 \mathrm{wt} . \%$. To improve the billet formation from the mix of finely ground frit and a secondary abrasive ( $\mathrm{SiC})$, the plasticizer (5 wt.\% of a kaolinite-illite clay) was used. The components of the bond, chopped to full passage through the sieve No. 0063, were mixed with diamond powder (AC6 125/100, 50 vol.\%) and briquetted at a relative pressure of $0.8 \mathrm{t} \mathrm{cm}^{-2}$. The composites were obtained by free sintering in a muffle furnace at the temperature of $650^{\circ} \mathrm{C}$ for $20 \mathrm{~min}$.

\section{Results and discussion}

The calculations showed that the stress level at the elevated pressure of $50 \mathrm{MPa}$ and the sintering temperature up to $400^{\circ} \mathrm{C}$ does not exceed the strength limits of grains AC6 125/100 brand diamond $\left(\sigma_{\text {ten }}=0.2\right.$ $\mathrm{GPa}$ ) grains, which indicates a slight effect of the force factor. With an increase in the sintering temperature up to $600^{\circ} \mathrm{C}$ or more in the grain in the metal-phase zone, tensions arise due to the difference in their thermal expansion coefficients, which causes the destruction of the grain. With an increase in the volumetric contents of the metal-phase inclusions, an exponential increase in the voltages localized near the metal-phase inclusions is observed. The presence of destructive stresses in microzones of the grain is not a sufficient condition for its damage. The destruction of grain begins when its volume, in which the limiting destructive voltages are fixed, exceeds more than $10 \%$.

In the modeling of the influence of metal-phase properties on the state of grains during sintering, the most typical alloys-solvents used in the synthesis of diamonds were considered: $\mathrm{Ni}_{39.6} \mathrm{Mn}_{59.6}\left(\mathrm{Cr}_{3} \mathrm{C}_{2}\right)_{0.8}$, $\mathrm{Fe}_{44} \mathrm{Co}_{44}\left(\mathrm{Cr}_{3} \mathrm{C}_{2}\right)_{12}$, and $\mathrm{Fe}_{95} \mathrm{Si}_{5}$ which differ significantly in values of thermal expansion coefficient and the elastic modulus [13]. It is established that nearly two-times increase in the value of thermal expansion coefficient of metal-phase leads to an increase in local equivalent stresses in a grain of 2.5-2.8 times. The critical level of stress is observed in certain microzones of the grain at $400^{\circ} \mathrm{C}$, but the destruction of a grain is possible only while heating above $700-750^{\circ} \mathrm{C}$ as the volume of critical stresses in a grain reaches $15-22 \%$ in this case. Under the conditions of sintering of a composite at $600-650^{\circ} \mathrm{C}$, the probability of destruction of grains is low, because the volume of critical stresses does not exceed $10 \%$.

The comparison of the temperature dependences of two grain destruction criteria with the data of experimental determinations of the integrity of the grains after sintering the composite samples showed that the relative volume of critical stresses in the grain $\left(\Delta \mathrm{V}_{\mathrm{cr}}\right)$ accurately reflects the degree of destruction of diamonds during the sintering of the diamond-bearing layer. Therefore, in order to determine the rational temperature of sintering the diamond-bearing layer, we used the very parameter that characterizes the relative volume of the grains in which stresses for the diamond's destruction of certain grades and graininess are present. The limits of the values of this parameter have been determined $\left(\Delta \mathrm{V}_{\mathrm{cr}}=3-7 \%\right)$, at which the grains in the composite are in the state of predestruction, the main feature of which is the formation of microcracks in the grain without loss of its integrity. According to the accepted working hypothesis, such state of grains is a prerequisite for their rational self-sharpening while grinding, as well as for the preventing of their premature destruction during the sintering of the diamond-bearing layer of the tool. The mathematical treatment of the results of model calculations allowed determining the range of temperatures of sintering diamond wheel capable of rational self-sharpening (Table).

Experimental verification confirmed this 
The recommended temperatures for sintering of ceramic-matrix composite using the diamond powder of different grades and graininess

\begin{tabular}{c|c|c|c|c|c|c|c|c|c|c|c|c}
\hline \multirow{2}{*}{$\begin{array}{c}\text { Graininess } \\
\text { of the } \\
\text { diamonds }\end{array}$} & \multicolumn{10}{|c|}{ Grade diamond grains } \\
\cline { 2 - 16 } & $\sigma_{\mathrm{p}}$ & $\mathrm{T}_{\min }$ & $\mathrm{T}_{\max }$ & $\sigma_{\mathrm{p}}$ & $\mathrm{T}_{\min }$ & $\mathrm{T}_{\max }$ & $\sigma_{\mathrm{p}}$ & $\mathrm{T}_{\min }$ & $\mathrm{T}_{\max }$ & $\sigma_{\mathrm{p}}$ & $\mathrm{T}_{\min }$ & $\mathrm{T}_{\max }$ \\
\hline $50 / 40$ & 0.35 & 666 & 687 & 0.6 & 692 & 719 & 0.84 & 710 & 737 & 2 & 763 & 795 \\
\hline $63 / 50$ & 0.22 & 649 & 672 & 0.37 & 676 & 701 & 0.67 & 700 & 728 & 1.4 & 748 & 779 \\
\hline $80 / 63$ & 0.14 & 632 & 653 & 0.27 & 662 & 688 & 0.41 & 686 & 715 & 0.88 & 731 & 761 \\
\hline $100 / 80$ & 0.09 & 614 & 635 & 0.19 & 650 & 675 & 0.27 & 670 & 698 & 0.59 & 718 & 749 \\
\hline $125 / 100$ & 0.07 & 600 & 622 & 0.12 & 634 & 660 & 0.20 & 658 & 686 & 0.53 & 706 & 737 \\
\hline $160 / 125$ & 0.05 & 583 & 604 & 0.11 & 625 & 652 & 0.14 & 644 & 671 & 0.28 & 689 & 721 \\
\hline $200 / 160$ & 0.03 & 568 & 590 & 0.07 & 610 & 635 & 0.11 & 633 & 661 & 0.2 & 674 & 705 \\
\hline $250 / 200$ & - & - & - & - & - & - & 0.07 & 619 & 648 & 0.14 & 661 & 691 \\
\hline
\end{tabular}

Note: $\sigma_{\mathrm{p}}$ is given in GPa; temperatures are given in ${ }^{0} \mathrm{C}$.

assumption. It was found by electron microscopy study that microcracks in the grain were formed at the recommended temperature of sintering the composite. However, the microcracks did not destroy the diamond grains while sintering the ceramicmatrix composite and created the prerequisites for their rational self-sharpening during the grinding.

Using multivariate experiment, the regression equations have been obtained that describe the dependence of selected criteria for the destruction of grains on the basic properties of components of diamond wheel under conditions simulating the processes of their production. The results of the simulation experiment allowed determining the optimum values of the properties of the diamondbearing layer and the sintering temperature: thermal expansion coefficient of the metal phase $\alpha_{\mathrm{Me}}=(1.2 \div 1.4) \cdot 10^{-5} 1 /{ }^{0} \mathrm{C}$; thermal expansion coefficient of the bond $\alpha=(6.0 \div 6.8) \cdot 10^{-6} 1 /{ }^{\circ} \mathrm{C}$; the elasticity modulus of the bond $\mathrm{E}=112 \div 120 \mathrm{GPa}$, and the temperature of sintering the diamond-bearing layer $\mathrm{T}_{\text {sint }}=620 \div 655^{\circ} \mathrm{C}$. Using the simplex-lattice experimental design, the relation between grains, bonds and pores have been determined that satisfy the given optimization conditions and can vary from $1: 1.4: 1.6$ to $1: 2: 2$.

The analysis of the composition of the model oxide compositions $\mathrm{R}_{2} \mathrm{O}-\mathrm{B}_{2} \mathrm{O}_{3}-\mathrm{TiO}_{2}-\mathrm{SiO}_{2}$ $\left(\mathrm{R}_{2} \mathrm{O}=\mathrm{L}_{2} \mathrm{O}, \mathrm{Na}_{2} \mathrm{O}\right.$ or $\left.\mathrm{K}_{2} \mathrm{O}\right)$, and their properties determined by the calculation allowed us to select the base compositions to develop the low-melting vitrified bond, providing the specified temperature of sintering of the composite $\left(\mathrm{T}_{\text {sint }}=658 \div 686^{\circ} \mathrm{C}\right)$ and considering the diamonds grade and graininess (AC6 125/100). The composition of glass-ceramic bond should satisfy a number of technological criteria that determine the consolidation of the composite, eliminate the thermal degradation of diamonds during sintering, improve diamond retention in bond and provide the conditions for self-sharpening of grains during grinding.

As criteria for choosing the basis for the vitrified bond development, we considered properties conform to the bond properties, which were defined in the stage of simulation experiments. In particular, we examined four following properties: (i) the melting point $\left(T_{\text {melt }}=600 \div 625^{\circ} \mathrm{C}\right)$ that ensures a lowering of the sintering temperature of the composite to $620 \div 655^{\circ} \mathrm{C}$; (ii) a relatively low thermal expansion coefficient $\left(\alpha_{20-600^{\circ} \mathrm{C}}=(6 \div 7) \cdot 10^{-6}, 1 /{ }^{\circ} \mathrm{C}\right)$; (iii) the elevated modulus of elasticity $(\mathrm{E}=110 \div 120 \mathrm{GPa})$ which is achieved due to the finely-dispersed crystallization of the glass phase: (iv) and the sintering properties of the melt (viscosity $\eta \leq 10^{3} \mathrm{~Pa}$ s and surface tension $\sigma \leq 0.3 \mathrm{~N} / \mathrm{m}$ ) which ensure the satisfactory wetting of the grains and sintering the composite at a given temperature.

Solutions of the optimization task were obtained taking into account the accepted limitations of properties. The optimal composition was calculated by solving the system of equations for the specified values of the target function. As a result, the chemical composition of the glass composition bond was selected, wt.\%: $25 \mathrm{Na}_{2} \mathrm{O} ; 5 \mathrm{~K}_{2} \mathrm{O} ; 5 \mathrm{Li}_{2} \mathrm{O} ; 6 \mathrm{~B}_{2} \mathrm{O}_{3}$; $3 \mathrm{Al}_{2} \mathrm{O}_{3} ; 22 \mathrm{TiO}_{2} ;$ and $34 \mathrm{SiO}_{2}$. The developed vitrified bond shows the following properties: $\mathrm{T}_{\text {melt }}=620^{\circ} \mathrm{C}$, thermal expansion coefficient of $6.9 \cdot 10^{-6} 1 / \mathrm{K}$; and $\mathrm{E}=115 \mathrm{GPa}$.

According to the results of X-ray diffraction analysis (Fig. 2), the crystallization of the phases of lithium metatitanate $\left(\mathrm{Li}_{2} \mathrm{TiO}_{3}\right)$ and lithium pentatitanate $\left(\mathrm{Li}_{4} \mathrm{~T}_{5} \mathrm{O}_{12}\right)$ was observed when ceramic 
bond was heated in the range of temperatures of 600 to $620^{\circ} \mathrm{C}$. The crystallization of these phases was also confirmed by the differential-thermal analysis (the data are not shown).

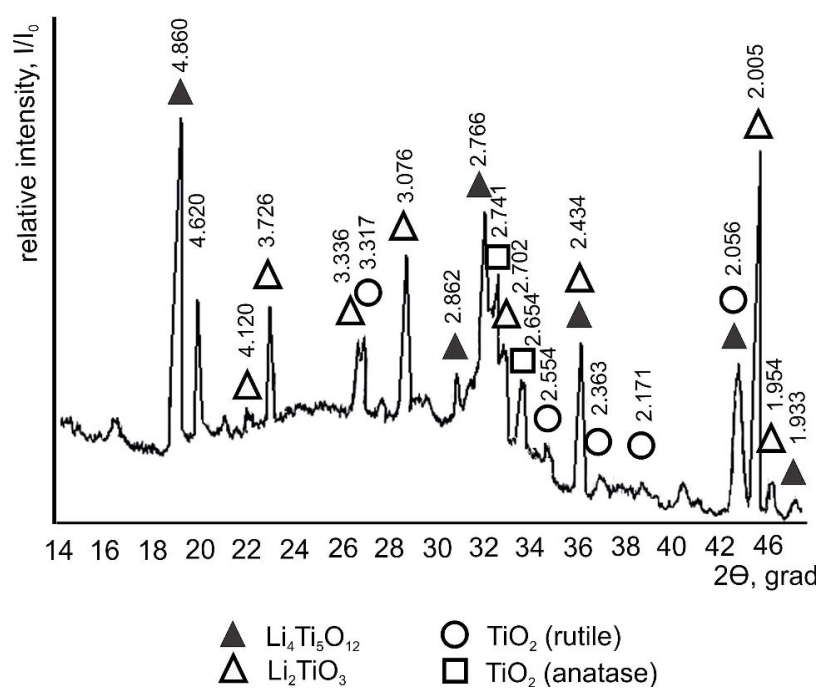

Fig. 2. Fragment of the X-ray pattern of the developed vitrified bond

For the samples of ceramic composites prepared using the developed bond, the integrity of the grains after sintering was determined. The results showed that the degree of the destruction of grains does not exceed $10 \%$ when using the developed vitrified bond, while the fraction of the destroyed grains is 37\% when using the typical bond K1-01. A positive technical effect is obtained by reducing the temperature of sintering the composite (from $750^{\circ} \mathrm{C}$ to $650^{\circ} \mathrm{C}$ for a typical ceramic bond $\mathrm{K} 1-01$ and for the developed low-melting vitrified bond, respectively) and optimization of bonds properties.

Qualitative and quantitative estimation of grain wear at different stages of grinding was carried out by topographic study of the working surface of diamond wheels (WWS) after grinding for $10 \mathrm{~s}$ and $3 \mathrm{~min}$. The study was performed using laser scanning microscopy. Observed insignificant changes in the relative support surface area of the samples $\left(\mathrm{t}_{\mathrm{ps}}=0.45-\right.$ $0.60 \%$ ) indicated that the wear of the WWS during grinding does not occur due to the loss of grains from the bond and because of the gradual microdestruction of those areas that lost cutting power during grinding.

SEM images of the films of WWS-zone after grinding show areas of grain wear-out, cracking in grains and micro-splits which form new cutting surfaces (Fig. 3). The contact zone of the bond and the grains exhibits good adhesion which increases diamond retention in the bond during grinding. With a large magnification $(\times 10,000)$, it is possible to observe the cryptocrystalline structure of the bond (Fig. 3,a), the morphology of the contact zone of the bond and the grain (Fig. 3,b), the grain wearout areas (Fig. 3,c), the shape of the contact cracks (Fig. 3,d), and microcracks in grains (Fig. 3,e), which cause updating of the cutting faces in the places of micro-splits (Fig. 3,f).

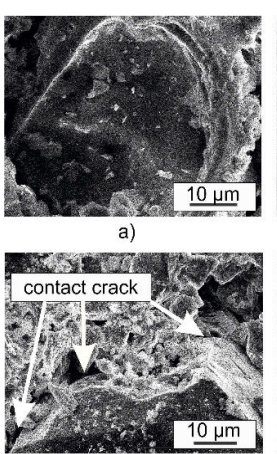

d)

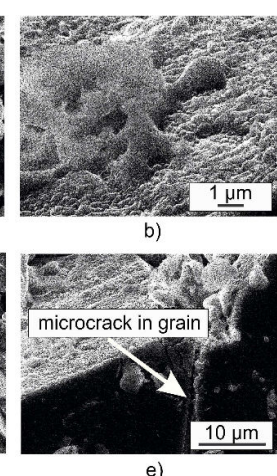

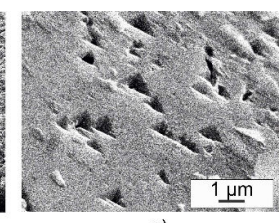

c)

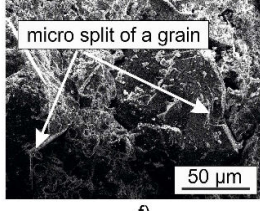

Fig. 3. SEM images of the areas of the working surface of diamond wheel after grinding: a) cryptocrystalline bond;

b) contact zone of grain and bond; c) grain wear-out area;

d) crack in the contact of grain and bond; e) micro-crack in grain; f) micro-splits in the areas of grain wear-out

Based on the analysis and generalization of the obtained results, a mechanism of the self-sharpening of diamond wheels during grinding was developed. Seemingly, sintering the diamond-bearing layer at the recommended temperature results in the appearance of stresses in diamond grains that meet the condition $\Delta \mathrm{V}_{\mathrm{cr}}=3 \div 7 \%$. As a result, micro-cracks are formed in the grains that are in the pre-destruction state (Fig. 4,a). During the grinding, the cutting faces of the grain are updated by the development of cracks directly on the wear-out areas, since it is precisely on these areas the temperature sharply rises due to an increase of the surface area of the grains, which contact with the processing material (Fig. 4,b-4,f). The removal of grains that have completely lost their cutting ability from the WWS occurs as a result of the appearance of stresses that exceed the bond's strength and cause its destruction on the contacts with the grains (Fig. 4,g - 4,h).

The samples of diamond wheels, manufactured according to the given recommendations, were tested at the LLC «Instail». To assess the ability of the tool to rational self-sharpening during grinding, we determined the relative consumption of diamond grains and the sizes of their wear areas after grinding 


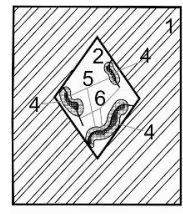

a)

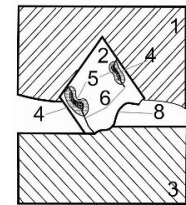

e)

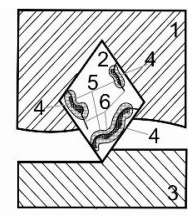

b)

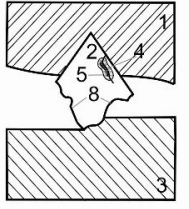

f)

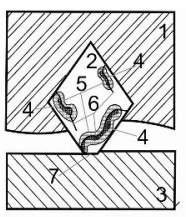

c)

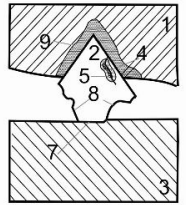

g)

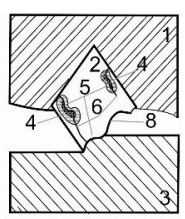

d)

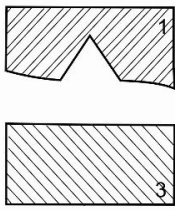

h)
Fig. 4. Mechanism of self-sharpening of diamond grain during grinding: 1 - vitrified bond; 2 - diamond grain; 3 - processing material; 4 - inclusion of metal phase;

5 - area with local critical stresses in grain;

6 - developed micro-cracks leading to the destruction of grain;

7 - areas of grain wear-out; 8 - updated cutting surfaces

formed as a result of splits on micro-cracks;

9 - the contact zone «bond-grain» where the stresses exceeds the bond strength

of hard alloy with the use diamond wheels on vitrified bond. The dependence of these characteristics on the grinding modes (Fig. 5) indicates that selfsharpening of grains is manifested in accelerated processing mode when grinding solid alloy (VK8): the average size of areas of grains wear is reduced by $\sim 25 \div 30 \%$ with increasing speed of grinding. With an increase in the speed of grinding $(>35 \mathrm{~m} / \mathrm{s})$, the wear of the diamond-bearing layer was increased. The specific consumption of diamonds significantly increased with an increase in the transverse feed (more than $0.02 \mathrm{~mm} /$ double path).

\section{Conclusions}

The results of the work showed that the used approach to design of diamond-made abrasive tools on the basis of finite-element modeling allowed giving recommendations to manufacturers of diamond wheels that made it possible to increase the resources of tools due to rational self-sharpening during the grinding. The proposed procedure of the fabrication of a low-melting vitrified bond with specified properties ensures receiving ceramic-matrix composite at a reduced sintering temperature (620$650^{\circ} \mathrm{C}$ ). This prevents premature destruction of diamond grains at the stage of the tool manufacturing, increases the diamond retention in the working layer of the tool and ensures its rational self-sharpening when grinding. It has been established that rational self-sharpening of DAT is provided at the stage of sintering the diamondiferous layer under the condition of stresses occur which causes the formation of micro-cracks without grains lossintegrity. To determine the necessary sintering parameters that ensure the fulfillment of the specified condition, the criterion $\Delta \mathrm{V}_{\text {cr }}$ was used which determines the stress state of the grains. The values of this parameter were determined at which the grains are in the pre-destruction state $\left(\Delta \mathrm{V}_{\mathrm{cr}}=3-7 \%\right)$. Using the proposed criterion, the sintering temperatures of ceramic-matrix diamond-containing composites are chosen considering the grade and graininess of diamond powders.

\section{REFERENCES}

1. Uede $K$. Latest technical trends of machine tools // Koyo Engineering Journal English Edition. - 2004. - No. 165E. - P.14-19.

2. Klocke F., Barth S., Mattfeld P. High performance grinding // Procedia CIRP. - 2016. - Vol. 46. - P.266-271.

3. Rowe W.B. Principles of modern grinding technology. - USA: Elsevier, 2014. - 480 p.
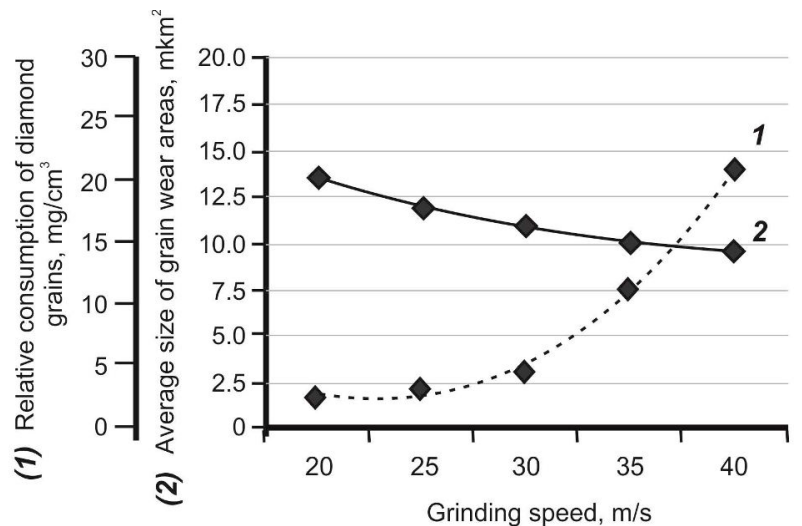

b

Fig. 5. Processing parameters of grinding in self-sharpening mode: a) grinding speed; b) transverse feed 
4. Chen Y., Zhang L. Polishing of diamond materials: mechanisms, modeling and implementation. - London: Springer, 2013. - $174 \mathrm{p}$.

5. Staniewicz-Brudnik B., Plichta J., Nadolny K. Effect of porous glass-ceramic materials addition on the cubic boron nitride (cBN) tools properties // Optica Applicata. - 2005. - Vol.35. No. 4. - P.809-817.

6. Boland J.N., Li X.S. Microstructural characterisation and wear behaviour of diamond composite materials // Materials. - 2010. - Vol.3. - P.1390-1419.

7. Substantiation of a concept of a selective destruction of diamond synthesis product / Majstrenko A.L., Novikov N.V., Bogatyreva G.P., Olejnik N.A. // Sverkhtverdye Materialy. 2005. - No. 1. - P.17-27.

8. Thermal stability of ultrahard polycrystalline diamond composite materials / Meng D., Yue W., Lin F., Wang C., Wu Z. // Journal of Superhard Materials. - 2015. - Vol.37. - P.67-72.

9. Diamond grinding wheels production study with the use of the finite element method / Kundrak J., Fedorovich V., Markopoulos A.P., Pyzhov I., Kryukova N. // Journal of Advanced Research. - 2016. - Vol.7. - P.1057-1064.

10. Semenov A.A. Analysis of the strength of shell structures, made from modern materials, according to various strength criteria // Diagnostics, Resource and Mechanics of Materials and Structures. - 2018. - No. 1. - P.16-33.

11. Calculation of the surface tension of molten borosilicate glasses / Goleus V.I., Belyi A.Ya., Sardak E.M., Belyi Ya.I. // Glass and Ceramics. - 1996. - Vol.53. - P.226-228.

12. Scholze H. Glass: nature, structure, and properties. New York: Springer Science \& Business Media, 2012. - 454 p.

13. Simulation of the effect of sintering on the integrity of diamond grains in grinding wheels / Grabchenko A.I., Romashov D.V., Fedorenko D.O., Mamalis A.G., Lagoudas D., Fedorovich V.I., Baxevanis Th. // Nanotechnology Perceptions. - 2014. - No. 10(1). - P.42-53.

Received 17.10.2018

\section{ЛЕГКОПЛАВКІ СКЛОКЕРАМІЧНІ ЗВ'ЯЗКИ НА ОСНОВІ ОКСИДНИХ КОМПОЗИЦІЙ ДЛЯ АЛМАЗНО- АБРАЗИВНИХ ІНСТРУМЕНТІВ}

\section{О.Ю. Федоренко, К.Б. Богданова, Д.О. Федоренко, Н.Ф. Лісних, Н.М. Регеда}

За результатами комп 'ютерного моделювання процесів, що супроводжсють виготовлення алмазно-абразивного інстру менту визначено раціональні характеристики структурнофазових складових алмазоносного шару, фізико-механічні і теплофізичні властивості зв 'язки. Для оцінювання стану зерен та їх здатності до самозагострення запропоновано структурний критерій $\Delta V_{\kappa p}$, що характеризує відносний об 'єм алмазів певноі марки і зернистості, напруги в яких сягають критичного рівня $\left(\Delta V_{\kappa p}>10 \%\right)$ та спричиняють руйнування зерен. Здійснено проектування складу та визначені умови спікання алмазоносного шару для реалізації раціонального самозагострення зерен при шліфуванні алмазними кругами. На основі оксидних композицій системи $\mathrm{R}_{2} \mathrm{O}-\left(\mathrm{Na}_{2} \mathrm{O}, \mathrm{K}_{2} \mathrm{O}\right)-\mathrm{B}_{2} \mathrm{O}_{3}-\mathrm{TiO}_{2}-\mathrm{SiO}_{2}$ розроблено легкоплавку склокерамічну зв'язку з наступними властивостями: температурний коефіцієнт лінійного розширення $\alpha=6,9 \cdot 10^{-6} 1 /{ }^{\circ} \mathrm{C} ;$ модуль пружності $E=115$ ГПа, яка забезпечуе спікання алмазоносного шару при температурі $T_{c n}=620^{\circ} \mathrm{C}$. Для виготовлених алмазних кругів визначено залежності питомоі втрати алмазів та розмірів ділянок зносу зерен від режимів шліфування та встановлено, що при обробленні твердих сплавів (ВK-8) самозагострення інструменту відбувається за наступних параметрів процесу: швидкість шліфування $30 \mathrm{~m} / \mathrm{c}$, поперечна подача 0,02 мм/подв.хід. За результатами аналізу топологічних параметрів та електронно-мікроскопічних досліджень робочої поверхні алмазних кругів після шліфування визначено механізм відновлення ріжучої здатності зерен, завдяки якому відбувається шліфування алмазно-абразивним інструментом в режсимі самозагострення та збільшується ресурс його експлуamauiï.

Ключові слова: алмазні круги, ріжуча здатність, самозагострення, алмазоносний шар, вітрифікована зв'язка, структурно-фазові складові.

\section{LOW-MELTING GLASS-CERAMIC BONDS BASED ON OXIDE COMPOSITIONS FOR DIAMOND-ABRASIVE TOOLS}

O.Yu. Fedorenko ${ }^{a,}{ }^{*}$, K.B. Bohdanova ${ }^{a}$, D.O. Fedorenko ${ }^{a}$, N.F. Lesnych ${ }^{b}$, N.M. Reheda ${ }^{a}$

a National Technical University «Kharkiv Polytechnic Institute», Kharkiv, Ukraine

b University of Applied Sciences, Technology, Business and Design, Wismar, Germany

*e-mail: fedorenko_e@ukr.net

Rational characteristics of the structural-phase constituents of the diamond-bearing layer and required physical-mechanical and thermophysical properties of the bond were determined based on the results of computer simulation of the processes accompanying the manufacture of the diamond-abrasive tool. To assess the state of diamond, taking into account its brand and graininess, a structural criterion, $\Delta V_{c r}$, is proposed that characterizes the grain relative volume in which the stresses reach a critical level $\left(\Delta V_{c r}>10 \%\right)$ and cause the grains destruction. The composition is designed and the sintering conditions of the diamond-bearing layer are determined to ensure rational self-sharpening of grains during grinding. On the basis of the oxide compositions of the $\mathrm{R}_{2} \mathrm{O}-\left(\mathrm{Na}_{2} \mathrm{O}, \mathrm{K}_{2} \mathrm{O}\right)-\mathrm{B}_{2} \mathrm{O}_{3}-\mathrm{TiO}_{2}-\mathrm{SiO}_{2}$ system, a low-melting glass-ceramic bond is developed which have the following properties: thermal expansion coefficient of $6.9 \cdot 10^{-6} 1 /{ }^{\circ} \mathrm{C}$ and elastic modulus of $115 \mathrm{GPa}$. The low-melting glass-ceramic bond provides the sintering of a diamond-bearing layer at the temperature of $620^{\circ} \mathrm{C}$. The dependence of the specific diamond's loss and the grains wear areas size on the grinding regimes was determined for fabricated diamond wheels. It was established that during the processing of hard alloys $(V K-8)$ the self-sharpening of $a$ tool occurs at the following process parameters: grinding speed of 30 $\mathrm{m} / \mathrm{s}$, cross-feed of $0.02 \mathrm{~mm} /$ double stroke. The analysis of the results of the topological parameters and electron microscopic studies of the diamond wheels after grinding allows us to develop a mechanism of the grains cutting capacity restoration, according to which the grinding with the diamond-abrasive tool occurs in self-sharpening mode that ensures an increase in its operation resource.

Keywords: diamond wheel; cutting ability; self-sharpening; diamond-bearing layer; vitrified bond; structural-phase components.

\section{REFERENCES}

1. Uede K. Latest technical trends of machine tools. Koyo 
Engineering Journal English Edition, 2004, no. 165E, pp. 14-19.

2. Klocke F., Barth S., Mattfeld P. High performance grinding. Procedia CIRP, 2016, vol. 46, pp. 266-271.

3. Rowe W.B. Principles of modern grinding technology. Elsevier, 2014. $480 \mathrm{p}$.

4. Chen Y., Zhang L. Polishing of diamond materials: mechanisms, modeling and implementation. Springer, 2013. $174 \mathrm{p}$.

5. Staniewicz-Brudnik B., Plichta J., Nadolny K. Effect of porous glass-ceramic materials addition on the cubic boron nitride (cBN) tools properties. Optica Applicata, 2005, vol. 35, no. 4, pp. 809-817.

6. Boland J.N., Li X.S. Microstructural characterisation and wear behaviour of diamond composite materials. Materials, 2010, vol. 3, pp. 1390-1419.

7. Majstrenko A.L., Novikov N.V., Bogatyreva G.P., Olejnik N.A. Substantiation of a concept of a selective destruction of diamond synthesis product. Sverkhtverdye Materialy, 2005, no. 1 , pp. 17-27.

8. Meng D., Yue W., Lin F., Wang C., Wu Z. Thermal stability of ultrahard polycrystalline diamond composite materials. Journal of Superhard Materials, 2015, vol. 37, pp. 67-72.

9. Kundrak J., Fedorovich V., Markopoulos A.P., Pyzhov I., Kryukova N. Diamond grinding wheels production study with the use of the finite element method. Journal of Advanced Research, 2016, vol. 7, pp. 1057-1064.

10. Semenov A.A. Analysis of the strength of shell structures, made from modern materials, according to various strength criteria. Diagnostics, Resource and Mechanics of Materials and Structures, 2018, no. 1 , pp. 16-33.

11. Goleus V.I., Belyi A.Ya., Sardak E.M., Belyi Ya.I. Calculation of the surface tension of molten borosilicate glasses. Glass and Ceramics, 1996, vol. 53, pp. 226-228.

12. Scholze H., Glass: nature, structure, and properties. Springer Science \& Business Media, New York, 2012. 454 p.

13. Grabchenko A.I., Romashov D.V., Fedorenko D.O., Mamalis A.G., Lagoudas D., Fedorovich V.I., Baxevanis Th. Simulation of the effect of sintering on the integrity of diamond grains in grinding wheels. Nanotechnology Perceptions, 2014, no. $10(1)$, pp. $42-53$. 